\title{
Tuberculosis outbreak in intensive swine farming from southern Brazil
}

\author{
Bruna Correa Lopes ${ }^{1}$ (i) Marina Roth Vidaletti ${ }^{2}$ (i) Daniel Holanda Soares $^{3}$ (i) \\ Fernando Froner Argenta ${ }^{1}$ (D) Lauren Santos de Mello ${ }^{1}$ (i) Saulo Petinatti Pavarini ${ }^{1}$ (i) \\ Fabiana Quoos Mayer $^{2 *}$ (D) David Driemeier ${ }^{1}$ (i)
}

'Programa de Pós-graduação em Ciências Veterinárias. Faculdade de Veterinária, Universidade Federal do Rio Grande do Sul (UFRGS), Porto Alegre, RS, Brasil.

${ }^{2}$ Centro de Pesquisa em Saúde Animal, Instituto de Pesquisas Veterinárias Desidério Finamor (IPVDF), Departamento de Diagnóstico e Pesquisa Agropecuária, Secretaria de Agricultura, Pecuária e Desenvolvimento Rural, 92990-000, Eldorado do Sul, RS, Brasil. E-mail: bimmayer@gmail.com. "Corresponding author.

${ }^{3}$ Ministério da Agricultura, Pecuária e Abastecimento (MAPA), Porto Alegre, RS, Brasil.

ABSTRACT: Mycobacterium tuberculosis var. bovis is the etiologic agent of animal tuberculosis (aTB), a neglected zoonotic disease. Animal tuberculosis can affect many species, including swine. aTB-consistent granulomas in these animals lead to carcass disposal, generating economic losses and posing risks to human health. In the present study, an aTB outbreak was identified at an intensive swine farming operation in Southern Brazil. Inspection during swine slaughter revealed aTB-suspected lesions, which were collected for diagnosis by histology, PCR, and bacterial isolation. The animals had no clinical signs of tuberculosis. Granulomatous lesions were identified in $0.73 \%(59 / 8,071)$ of the slaughtered swine, and were confirmed by histology. Nine samples were further examined by PCR and bacterial isolation, with $44.4 \%$ and $55.5 \%$ positive results, respectively. Data from abattoirs subjected to federal surveillance show an aTB prevalence in Brazil of $<0.001 \%$. The present data thus indicate a swine aTB outbreak in intensive breeding. Swine infection can be related to exposure to infected animals or to contaminated food or environment. Biosecurity measures must be taken to avoid aTB transmission. Although certified swine breeding farms adopt such measures, this report indicates that constant monitoring is crucial, and greater control in swine breeding and finishing units is required to prevent outbreaks and spread of tuberculosis.

Key words: zoonosis, one health, Mycobacterium tuberculosis var. bovis, PCR, pigs.

Surto de tuberculose em suínos de criação intensiva no Sul do Brasil

RESUMO: Mycobacterium bovis é o agente etiológico da tuberculose animal (aTB), uma doença zoonótica negligenciada. A tuberculose animal pode afetar muitas espécies, incluindo suínos. Os granulomas compativeis com a aTB nesses animais levam ao descarte de carcaças, gerando perdas econômicas e trazendo riscos à saúde humana. No presente estudo, um surto de aTB foi identificado em um sistema de criação intensiva de suínos na região Sul do Brasil. A inspeção durante um abate de suínos revelou lesões suspeitas de tuberculose, as quais foram coletadas para diagnóstico por histologia, PCR e isolamento bacteriano. Os animais não apresentavam sinais clínicos de tuberculose. Lesões granulomatosas foram identificadas em 0,73\% (59/8.071) dos suínos abatidos, e foram confirmadas pela histologia. Nove amostras foram posteriormente examinadas por PCR e isolamento bacteriano, com 44,4\% e 55,5\% de resultados positivos, respectivamente. Dados de frigorificos submetidos à vigilância federal demostram prevalencia da aTB de $<0,001 \%$ no Brasil. Os dados presentes indicam, portanto, um surto de aTB em suínos de criação intensiva. A infecção em suínos pode estar relacionada à exposição a animais infectados, alimentos ou ambientes contaminados. Medidas de biossegurança devem ser tomadas para evitar a transmissão da aTB. Embora as granjas suinícolas certificadas adotem tais medidas, este relato indica que o monitoramento constante é crucial, e maior controle nas unidades de criação e terminação de suínos é necessário para prevenir surtos e disseminação da tuberculose.

Palavras-chave: zoonose, saúde unica, Mycobacterium bovis, PCR, Suínos.

Mycobacterium bovis causes animal tuberculosis (aTB), a neglected infectious zoonotic disease (WHO, 2010) that can affect wild and domestic species (BYRNE et al., 2019). Swine are susceptible to $M$. bovis infection, but infections in this species are uncommon compared with $M$. avium infections (COLDEBELLA et al., 2018). When granulomatous lesions are identified during carcass examinations, 
most lesions are related to lymphadenitis, caused by $M$. avium complex bacteria (STROMEROVA; FALDYNA, 2018). Data from abattoirs under federal surveillance show that aTB prevalence was $<0.001 \%$, and lymphadenitis prevalence was $0.81 \%$ between 2012 and 2014 in Brazil (COLDEBELLA et al., 2018).

The presence of aTB-compatible granulomas leads to partial or whole carcass condemnation, contributing to economic loss (BRASIL, 2017). Each year, 3,974 kilotons of pork are produced in Brazil and about $84 \%$ is directed to domestic markets (ABPA, 2019). Therefore, biosecurity measures during pig rearing and finishing, together with monitoring and surveillance measures must be taken to prevent infection of animals with $M$. bovis, and ensure that infected animals do not reach human consumers. This study described an outbreak of M. bovis in swine from production facility in Rio Grande do Sul, Brazil.

During a slaughter that occurred in February 2019 in the central region of Rio Grande do Sul State, southern Brazil, 59 swine among a total of $8,071(0.73 \%)$ presented granulomatous lesions at post-mortem examination, these animals were approximately 4 to 5 months old. The positive animals were from three different finishing farms, but were traced to the same piglet production unit. Lesions were found in all submandibular and pulmonary lymph nodes, and in some mesenteric lymph nodes, livers, and spleens. Lesions were grossly characterized by multifocal to coalescent nodular areas of 0.3 to $1.5 \mathrm{~cm}$, white to yellowish, firm, with caseous appearance. The animals had no clinical signs of tuberculosis and had a normal body score during pre-slaughter evaluation.

Of the 59 animals, 22 were sampled, of which 29 tissues were submitted for histological diagnosis according to standard protocols. For histological analyses, fragments of the affected organs were harvested and fixed in $10 \%$ neutral buffered formalin. Thin slices were then processed and stained with Haematoxylin and Eosin (HE) and Ziehl Neelsen. Nine samples, each from a different animal, were randomly selected for PCR and bacterial isolation. For molecular analyses, DNA was extracted from fragments of affected tissues, and subjected to PCR specific to M. tuberculosis var. bovis as previously described (LOPES et al., 2020; MAYER et al., 2012). For mycobacterial isolation, after decontamination using the Petroff method, tissues were inoculated in Stonebrink-Leslie and Löwenstein-Jensen culture media (COUSINS,
2018). Samples were then aerobically incubated at $37^{\circ} \mathrm{C}$ until colonies with morphology compatible with $M$. bovis appeared. DNA was then extracted from colonies (VAN SOOLINGEN et al., 1991) and subjected to PCR specific to M. bovis using two different previously published protocols (WARREN et al., 2006; MAYER et al., 2012), confirming their identification as M. bovis.

All samples analysed by histology $(\mathrm{n}=$ 29) displayed granulomatous lesions suggestive of tuberculosis, described as multifocal nodular areas of caseous necrosis, often mineralized, surrounded by inflammatory infiltrate of epithelioid macrophages, multinucleated giant cells, lymphocytes, plasmocytes and neutrophils associated with peripheral fibrosis. None of the samples were positive at Ziehl Neelsen stain. By molecular diagnosis, 44.4\% (4/9) of samples tested positive for M. bovis. Following the bacterial isolation procedure, $55.5 \%$ (5/9) of samples presented colonies confirmed as $M$. bovis by PCR (Table 1). Only 2 samples gave positive results by both PCR and bacterial isolation.

Studies have identified M. avium Complex as the most important causative pathogens associated with swine granulomatous lesions; however, other authors have claimed the importance of $M$. bovis in regions that do not have bovine tuberculosis effectively under control (MUWONGE et al., 2012; BARANDIARAN et al., 2015). In Brazil, bovine tuberculosis is endemic, and data implicating $M$. bovis or $M$. avium in swine granulomatous lesions are scarce and largely limited to regional studies (COLDEBELLA et al., 2018).

In the outbreak described here, all tested cases were associated with $M$. bovis and were probably contracted on the breeding farm, since all positive animals had the same origin. Animal infections can be traced to exposure to other infected animals (e.g., swine, cattle, or humans), contaminated food, or environmental sources (ÁLVAREZ et al., 2011; BARANDIARAN et al., 2015; JOHANSEN et al., 2014; MESSENGER; BARNES; GRAY, 2014). Exposure to contaminated food is considered most relevant to swine, given their feeding habits (BARANDIARAN et al., 2015). However, high density swine farming systems in Rio Grande do Sul are mostly operated by cooperative companies, which guarantee tight control of the breeding process (MIELE; WAQUIL, 2007), and are considered less likely to have infections related to contaminated food in their systems. Genotyping the isolates obtained here would provide hints about the probable source of infection and should be performed in future studies. 
Table 1 - Analyzed samples and results. All samples were negative at Ziehl Neelsen at histology analysis.

\begin{tabular}{|c|c|c|c|c|}
\hline Animal & Tissue & Histology (HE) & Tissue PCR & Bacterial isolation \\
\hline 1 & Head lymph nodes & + & + & + \\
\hline \multirow{2}{*}{2} & Gastrohepatic lymph nodes & + & $\mathrm{np}$ & $\mathrm{np}$ \\
\hline & Spleen & + & $\mathrm{np}$ & $\mathrm{np}$ \\
\hline 3 & Pulmonary lymph nodes & + & - & + \\
\hline 4 & Neck lymph nodes & + & $\mathrm{np}$ & $\mathrm{np}$ \\
\hline 5 & Mesenteric lymph nodes & + & $\mathrm{np}$ & $\mathrm{np}$ \\
\hline 6 & Gastrohepatic lymph nodes & + & $\mathrm{np}$ & $\mathrm{np}$ \\
\hline 7 & Pulmonary lymph nodes & + & + & - \\
\hline 8 & Liver & + & $\mathrm{np}$ & $\mathrm{np}$ \\
\hline 9 & Liver & + & $\mathrm{np}$ & $\mathrm{np}$ \\
\hline \multirow{2}{*}{10} & Gastrohepatic lymph nodes & + & $\mathrm{np}$ & $\mathrm{np}$ \\
\hline & Pulmonary lymph nodes & & $\mathrm{np}$ & $\mathrm{np}$ \\
\hline 11 & Head lymph nodes & + & + & - \\
\hline 12 & Lymph nodes & + & + & + \\
\hline \multirow{2}{*}{13} & Liver & + & $\mathrm{np}$ & $\mathrm{np}$ \\
\hline & Spleen & + & $\mathrm{np}$ & $\mathrm{np}$ \\
\hline \multirow[t]{2}{*}{14} & Liver & + & $\mathrm{np}$ & $\mathrm{np}$ \\
\hline & Mesenteric lymph nodes & + & $\mathrm{np}$ & $\mathrm{np}$ \\
\hline 15 & Gastrohepatic lymph nodes & + & $\mathrm{np}$ & $\mathrm{np}$ \\
\hline 16 & Mesenteric lymph nodes & + & $\mathrm{np}$ & $\mathrm{np}$ \\
\hline \multirow[t]{2}{*}{17} & Lungs & + & $\mathrm{np}$ & $\mathrm{np}$ \\
\hline & Neck lymph nodes & + & $\mathrm{np}$ & $\mathrm{np}$ \\
\hline 18 & Mesenteric lymph nodes & + & - & + \\
\hline 19 & Head lymph nodes & + & $\mathrm{np}$ & $\mathrm{np}$ \\
\hline \multirow{2}{*}{20} & Liver & + & - & - \\
\hline & Spleen & + & $\mathrm{np}$ & $\mathrm{np}$ \\
\hline \multirow{2}{*}{21} & Lungs & + & - & - \\
\hline & Pulmonary lymph nodes & + & $\mathrm{np}$ & $\mathrm{np}$ \\
\hline \multirow{2}{*}{22} & Liver & + & $\mathrm{np}$ & $\mathrm{np}$ \\
\hline & Gastrohepatic lymph nodes & + & - & + \\
\hline
\end{tabular}

HE: Haematoxylin and Eosin; “+”: positive results; “-”: negative results; “np”: not performed.

Given the zoonotic potential of aTB, when cases are confirmed, investigations into the probable source of infection, and institution or review of management measures such as cleaning, disinfection, and temporary cessation of farm operations for sanitation are recommended. Providing regular employee instruction, and correctly disposing of carcasses are also recommended (BARCELLOS et al., 2008). In the present report, the weaner-producing farm was identified as the likely source of infection, the finishing farms were subjected to disinfection and a short break in operations, and the employees were instructed to seek health care. Although it was not possible to define the source of infection, biosafety measures such as preventing animals from having contact with infected animals (including infected humans), avoiding feeding them with milk and dairy products, and avoiding possible sources of environmental contamination could prevent the occurrence of future outbreaks.

Three different techniques were used for aTB diagnosis to characterize this aTB outbreak in domestic swine. Although all harvested samples had histological lesions compatible with aTB, not all samples were positive by bacterial isolation or PCR. Such discrepancies may occur due to factors such as number of viable microorganisms, and level of lesion calcification. We thus recommend using more than one test to confirm the disease, which should provide higher diagnostic accuracy, as has been suggested in previous reports (MEDEIROS et al., 2010; LOPES et al., 2020). 
Although less frequent, pigs may be responsible for zoonotic tuberculosis, rendering continuous monitoring of this species critical. Thus, certified swine breeding farms are tested at six-month intervals by random sampling using comparative tuberculin test (MAPA, 2002). Additionally, there is no direct contact between swine and other animal species. However, despite these efforts, this study shows an outbreak of tuberculosis in animals from the same piglet production unit, indicating that greater oversight is needed at extensive pig breeding units to prevent swine aTB outbreaks.

\section{ACKNOWLEDGEMENTS}

The authors are thankful for Ândrea Sara Dutra for the English language revision. BCL is recipient of CAPES scholarship (grant $\mathrm{n}^{\circ} 88887.337504 / 2019-00$ ) and DD is a CNPq $1 \mathrm{~A}$ fellow (grant $\mathrm{n}^{\circ} 310489 / 2020-2$ ). The project was financed in part by the Coordenação de Aperfeiçoamento de Pessoal de Nível Superior (CAPES), Brasil - Finance code 001.”

\section{ETHICS STATEMENT}

The manuscript does not contain clinical studies or patient data. Moreover, no animals were manipulated in the study, being the samples collected during a routine slaughter and diagnosis made in laboratory routine. The data/results of the manuscript are not plagiarism and have not been published elsewhere.

\section{DECLARATION OF CONFLICT OF} INTEREST

The authors declare that there are no conflicts of interest. The founding sponsors had no role in the design of the study; in the collection, analyses, or interpretation of data; in the writing of the manuscript, and in the decision to publish the results.

\section{AUTHORS' CONTRIBUTIONS}

All authors contributed to the report conception. The slaughterhouse inspection and detection of the lesions was made by Daniel Holanda Soares. The histological analysis was performed by Fernando Froner Argenta, Lauren Santos de Mello, Saulo Petinatti Pavarini and David Driemeier. The molecular analysis and bacterial isolation were performed by Bruna Correa Lopes, Marina Roth Vidaletti and Fabiana Quoos Mayer. The first draft of the manuscript was written by Bruna Correa Lopes under supervision of Fabiana Quoos Mayer and David Driemeier. All authors read and approved the final manuscript.

\section{REFERENCES}

ABPA. Relatório Anual da Associação Brasileira de Proteína Animal (2019). SÃO PAULO, SP: [s. n.], 2019. Available from: $<$ http://abpa-br.org/relatorios/>. Accessed: Oct. 12, 2019.

ÁLVAREZ, J. et al. Epidemiological investigation of a Mycobacterium avium subsp. hominissuis outbreak in swine.
Epidemiology and Infection, [s.l.], v.139, n.1, p.143-148, 2011. Available from: <https://doi.org/10.1017/S0950268810001779>. Accessed: Oct. 12, 2019.

BARANDIARAN, S. et al. Tuberculosis in swine co-infected with Mycobacterium avium subsp. hominissuis and Mycobacterium bovis in a cluster from Argentina. Epidemiology and Infection, [s. l.], v.143, n.5, p.966-974, 2015. Available from: <https://doi. org/10.1017/S095026881400332X>. Accessed: Oct. 12, 2019.

BARCELLOS, D. E. S. N. de et al. Advances in biosecurity programs in pig production. Acta Scientiae Veterinariae, [s.l.], v.36, n.Supl 1, p.33-46, 2008. Available from: <http://professor. pucgoias.edu.br/SiteDocente/admin/arquivosUpload/4753/ material/Biosseguridade3.pdf $>$. Accessed: Oct. 12, 2019.

BRASIL. Decreto No 9.013 de 29 de Março de 2017, Diário Oficial da UniãoDiário Oficial da União, Brasília, Brasília: 2017. p. 1-76. Available from: <http://www.planalto.gov.br/ ccivil_03/_ato2015-2018/2017/decreto/d9013.htm>. Accessed: Oct. $\overline{12}, 2 \overline{0} 19$.

BYRNE, A. W. et al. Editorial: Bovine tuberculosis - international perspectives on epidemiology and management. Frontiers in Veterinary Science, $[s$. l. $]$, v.6, p.1-5, 2019. Available from: $<$ https://doi.org/10.3389/fvets.2019.00202>. Accessed: Oct. 12, 2019.

COLDEBElla, A. et al. Avaliação dos dados de abate e condenações/desvios de suínos registrados no Sistema de Informações Gerenciais do Serviço de Inspeção Federal nos anos de 2012 a 2014. Embrapa Suínos e Aves. CONCÓRDIA, SC: EMBRAPA SUÍNOS E AVES, 2018. Available from: $<$ https://www.infoteca.cnptia.embrapa.br/infoteca/bitstream/ doc/1093942/1/final8762.pdf>. Accessed: Oct. 12, 2019.

COUSINS, D. V. Chapter 3.4.6. Bovine Tuberculosis. In: OIE TERRESTRIAL MANUAL 2018. 8th Editioed. [S. l.]: World Organization for Animal Health, 2018. p.1058-1074. E-book.

JOHANSEN, T. B. et al. Mycobacterium avium subsp. hominissuis infection in swine associated with peat used for bedding. BioMed Research International, [s.l.], v.2014, p.1-8, 2014. Available from: $<$ https://doi.org/10.1155/2014/189649>. Accessed: Oct. 12, 2019.

LOPES, B. C. et al. A molecular strategy to optimize bovine tuberculosis post-mortem diagnosis and the exposure to Mycobacterium tuberculosis variant bovis. Molecular Biology Reports, [s.l.], 2020. Available from: <https://doi.org/10.1007/ s11033-020-05718-7>. Accessed: Oct. 12, 2019.

MAPA. Instrução Normativa No 19, de 15 de Fevereiro de 2002. Diário Oficial da União publicado em $1^{\circ}$ de Março de 2002. Diário Oficial da União, Brasília, Brasília: Ministério da Agricultura, Pecuária e Abastecimento, 2002. Available from: <https://www. agricultura.rs.gov.br/upload/arquivos/201612/15143003-in-192002-normas-grsc.pdf>. Accessed: Oct. 12, 2019.

MAYER, F. Q. et al. Mycobacterium bovis infection in a collared peccary (Tayassu tajacu): Insights on tuberculosis wild reservoirs. Veterinary Microbiology, [s.l.], v.160, n.3-4, p.549-551, 2012. Available from: <https://doi.org/10.1016/j.vetmic.2012.06.033>. Accessed: Oct. 12, 2019.

MEDEIROS, L. dos S. et al. Potential application of new diagnostic methods for controlling bovine tuberculosis in Brazil. 
Brazilian Journal of Microbiology, [s.l.], v.41, n.3, p.531-541, 2010. Available from: <https://doi.org/http://dx.doi.org/10.1590/ S1517-83822010005000002>. Accessed: Oct. 12, 2019.

MESSENGER, A. M.; BARNES, A. N.; GRAY, G. C. Reverse zoonotic disease transmission (Zooanthroponosis): A systematic review of seldom-documented human biological threats to animals. PLoS ONE, [s. l.], v.9, n.2, p.1-9, 2014. Available from: <https:// doi.org/10.1371/journal.pone.0089055>. Accessed: Oct. 12, 2019.

MIELE, M.; WAQUIL, P. D. Cadeia Produtiva da Carne Suína no Brasil. Revista de Política Agrícola, [s.l.], v.16, n.1, p.75-87, 2007. Available from: <https://doi.org/10.1088/17425468/2004/12/P12002>. Accessed: Oct. 12, 2019

MUWONGE, A. et al. Mycobacterium bovis infections in slaughter pigs in Mubende district, Uganda: a public health concern. BMC Veterinary Research, v.8, p.168, 2012. Available from: <https:// doi.org/10.1186/1746-6148-8-168>. Accessed: Oct. 12, 2019.

STROMEROVA, N. H.; FALDYNA, M. Mycobacterium avium complex infection in pigs: A review. Comparative Immunology, Microbiology and Infectious Diseases, [s.l.], v.57, n. June, p.62-68, 2018. Available from: $<$ https://doi.org/10.1016/j. cimid.2018.06.005>. Accessed: Oct. 12, 2019.
VAN SOOLINGEN, D. et al. Occurrence and stability of insertion sequences in Mycobacterium tuberculosis complex strains: Evaluation of an insertion sequence-dependent DNA polymorphism as a tool in the epidemiology of tuberculosis. Journal of Clinical Microbiology, [s.l.], v.29, n.11, p.2578-2586, 1991. Available from: <https://doi.org/10.1128/jcm.29.11.25782586.1991>. Accessed: Oct. 12, 2019.

WARREN, N. C. et al. Differentiation of Mycobacterium tuberculosis complex by PCR amplification of genomic regions of difference. The International Journal of Tuberculosis and Lung Disease. v.10, n.7, p.818-822, 2006. Available from: <https://www.ingentaconnect.com/ content/iuatld/ijtld/2006/00000010/00000007/art00019;js essionid=3wejlir3aeej0.x-ic-live-01>. Accessed: Oct. 12, 2019.

WHO. The control of neglected zoonotic diseases : community based interventions for NZDs prevention and control: report of the third conference organized with ICONZ, DFID-RiU, SOS, EU, TDR and FAO with the participation of ILRI and OIE. World Health Organization. The Control of Neglected Zoonotic Diseases, [s. l.], n.3, p.1-83, 2010. Available from: <http://apps. who.int/iris/bitstream/10665/44746/1/9789241502528 eng.pdf>. Accessed: Oct. 12, 2019. 